\title{
COMPARISON OF VARIOUS ADVANCED OXIDATION PROCESSES FOR THE DEGRADATION OF BISPHENOL A
}

\author{
Naser Jamshidi ${ }^{a, c}$ * \\ Farzad Nezhad bahadori ${ }^{b}$ \\ Ladan Talebiazar ${ }^{c}$ \\ Ali Akbar Azimi ${ }^{d}$ \\ ${ }^{a}$ HSE Department, National petrochemical Co., Tehran, Iran \\ ${ }^{\boldsymbol{b}}$ Environmental Department, PET Zone, Mahshahr, Iran \\ ${ }^{c}$ Chemical Eng. Department, Urmia University of Technology, Iran \\ ${ }^{b}$ Civil Eng. Department, Ahar Branch, Islamic Azad University, Iran
}

\begin{abstract}
Today, advanced oxidation processes (AOPs) is considered as a key and effective method for environment preservation from pollutions. In this study, advanced photochemical oxidation processes using $\mathrm{O}_{3} / \mathrm{H}_{2} \mathrm{O}_{2}$ and $\mathrm{O}_{3} / \mathrm{H}_{2} \mathrm{O}_{2} / \mathrm{UV}$ systems were investigated batch photolytic reactor in lab-scale for the degradation of bisphenol A (BPA).

In ozone generator source, air, as the initial instrument feed, changes to ozone after electrical action and reaction. The UV irradiation source was a medium-pressure mercury lamp $300 \mathrm{~W}$ that was immerse in the wastewater solution with in 1.5 liter volume reactor. The reaction was influenced by the $\mathrm{pH}$, the input concentration of $\mathrm{H}_{2} \mathrm{O}_{2}$, the input concentration of BPA, ozone dosage, chemical oxidation demand (COD) and UV irradiation time.

Results showed that at initial bisphenol A concentration of $100 \mathrm{mg} / 1$ will completely degrade after 60 minutes by using $\mathrm{O}_{3} / \mathrm{H}_{2} \mathrm{O}_{2}$ in the $\mathrm{pH}$ range from 9.8 to 10 and by adding $\mathrm{UV}$, it will happen in less than 36 minutes in the $\mathrm{pH}$ range of 3 to 10 . The $\mathrm{O}_{3} / \mathrm{H}_{2} \mathrm{O}_{2} / \mathrm{UV}$ process reduced COD to 75 percents.
\end{abstract}

\section{KEYWORDS}

Bisphenol A, Ozone, UV, Degradation, Advanced Oxidation Processes, COD

\section{INTRODUCTION}

Recently, endocrine disrupting chemicals (EDCs) have been spread over the environment and have deteriorated the generative function of some species of living things on the earth [1]. Although, it is still being discussed whether such chemicals have an influence upon human beings or not, it is necessary to develop technology for their decomposition as soon as possible. Unfortunately, these EDCs cannot be degraded and removed completely by conventional biological degradation treatment. Consequently, advanced treatment technologies are required to effectively eliminate these environmental pollutants in drinking water sources and wastewater effluents [2-4]. 
Besides the works on removal or mineralization of these chemicals have been carried out using various advanced oxidation technologies (AOT) are effective in decomposing refractory organic chemicals [3-5]. In this study, $\mathrm{O}_{3}$ oxidation was chosen as the main chemical treatment to decompose bisphenol $\mathrm{A}$ in aqueous medium (Figure1).

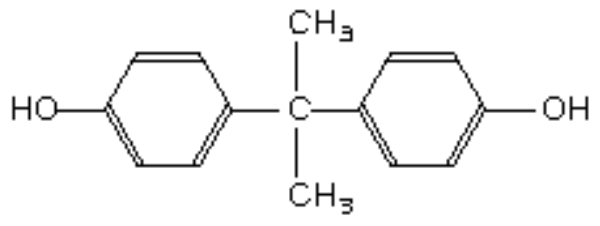

Figure 1. Structural formula of BPA.

BPA is a monomer of various polymeric materials. In addition to being used as monomers for the production of polycarbonates, epoxide phenol resins, etc., it is also being utilized as an antioxidant in numerous types of plastics [6].

Recent studies have shown that BPA can leach out of the plastic lining of cans used for foods, polycarbonate baby bottles, tableware, white dental fillings and sealents [7]. Epoxy resins used for the renovation of water pipes are based on BPA diglycidyl ether or a mixture of BPA and diglycidyl ether. Residues of this compound in water appear to be due to incomplete polymerization [8]. When BPA was subjected to metabolic activity it bounded to DNA [9]. $\mathrm{O}_{3}$ reacts with organic compounds through a direct pathway by molecular ozone and a radical pathway by means of hydroxyl radicals. Under acidic conditions and in presence of radical scavengers which inhibit the chain reaction which accelerates the decomposition of $\mathrm{O}_{3}$, the direct ozonation pathway dominates but under basic conditions or in presence of solutes which promote the radical-type chain reaction which accelerates the transformation of ozone into $\cdot \mathrm{OH}$ radicals the latter, i.e. hydroxyl radical reactions dominate $[10,11]$. When the medium is basic, $\mathrm{O}_{3}$ decomposes to generate hydroxyl radical, which is non-selective and highly reactive oxidant for destruction of toxic organic compounds in wastewater.

Ozone decomposition proceeds with chain reactions including initiation, propagation and termination steps $[11,12]$ :

- Initiation step:

Decomposition reaction of ozone is initiated by $\mathrm{OH}^{-}$ions in the solution yielding $\cdot \mathrm{OH}$ radicals.

$\mathrm{O}_{3}+\mathrm{OH}^{-} \rightarrow \mathrm{O}_{2}^{\cdot-}+\mathrm{HO}_{2}^{\cdot}$

$$
k_{1}=70 \mathrm{M}^{-1} \mathrm{~s}^{-1}
$$

- $\mathrm{HO}_{2}{ }^{\cdot}$ radical is in acid-base equilibrium:

$$
\mathrm{HO}_{2}^{\cdot}=\mathrm{O}_{2}^{\cdot-}+\mathrm{H}^{+}
$$

$$
\mathrm{p} K_{\mathrm{a}}=4.8
$$

- Propagation step:

$\mathrm{O}_{3}+\mathrm{O}_{2}^{\cdot-} \rightarrow \mathrm{O}_{3}^{\cdot-}+\mathrm{O}_{2}$

$$
k_{2}=1.6 \times 109 \mathrm{M}^{-1} \mathrm{~s}^{-1}
$$




$$
\begin{aligned}
& \mathrm{HO}_{3}{ }^{\cdot}=\mathrm{O}_{3}^{\cdot-}+\mathrm{H}^{+} \\
& \mathrm{HO}_{3}{ }^{\cdot} \rightarrow{ }^{\circ} \mathrm{OH}+\mathrm{O}_{2} \\
& \mathrm{O}_{3}+{ }^{\cdot} \mathrm{OH} \rightarrow \mathrm{HO}_{4}{ }^{\circ} \\
& \mathrm{HO}_{4}{ }^{\cdot} \rightarrow \mathrm{HO}_{2}{ }^{\cdot}+\mathrm{O}_{2}
\end{aligned}
$$

\section{- Termination step:}

This step includes any recombination of ${ }^{\circ} \mathrm{OH}, \mathrm{HO}_{2}{ }^{\circ}$ and $\mathrm{O}_{2}$. The combination of ultraviolet (UV) radiation with $\mathrm{O}_{3}$ may be a more effective advanced oxidation technique than using $\mathrm{O} 3$ alone for certain target materials due to the formation of additional $\mathrm{H}_{2} \mathrm{O}_{2}$ and ${ }^{\circ} \mathrm{OH}$ radical generation via photolysis [13].

$\mathrm{O}_{3}+\mathrm{H}_{2} \mathrm{O}+h v \rightarrow \mathrm{H}_{2} \mathrm{O}_{2}+\mathrm{O}_{2}$

$\mathrm{H}_{2} \mathrm{O}_{2}+h v \rightarrow 2^{\circ} \mathrm{OH}$

However, the photolysis of $\mathrm{H} 2 \mathrm{O} 2$ to produce two $\bullet \mathrm{OH}$ radicals is rather slow because molar extinction coefficient of hydrogen peroxide is much lower $\left(19.6 \mathrm{M}^{-1} \mathrm{~cm}^{-1}\right)$ than that of ozone $(3300 \mathrm{M}-1 \mathrm{~cm}-1)$ at $254 \mathrm{~nm}$ [14]. A fraction of hydrogen peroxide is dissociated into $\mathrm{HO}_{2}{ }^{-}$ $\left(\mathrm{p} K_{\mathrm{a}}=11.8\right)$ by following reaction [15]:

$$
\mathrm{H}_{2} \mathrm{O}_{2} \rightarrow \mathrm{HO}_{2}^{-}+\mathrm{H}^{+}
$$

This reacts with further ozone by producing $\mathrm{O}_{3}{ }^{\cdot-}$ radicals,

$$
\mathrm{HO}_{2}^{-}+\mathrm{O}_{3} \rightarrow \mathrm{HO}_{2}{ }^{-}+\mathrm{O}_{3}{ }^{-}
$$

and it therefore acts as a further chain carrier [11].

In this study BPA were treated with $\mathrm{O}_{3}, \mathrm{O}_{3} / \mathrm{H}_{2} \mathrm{O}_{2}$ and $\mathrm{O}_{3} / \mathrm{H}_{2} \mathrm{O}_{2} / \mathrm{UV}$ in aqueous medium at 100 $\mathrm{mg} / \mathrm{L}$ initial concentration. The depletion of the initial substrates throughout the treatments were monitored and the efficiency of conversions and complete degradations in three different systems were compared.

\section{MATERIALS AND METHODS}

\subsection{Chemical}

Bisphenol A (99\%; Aldrich, $228.29 \mathrm{~g} / \mathrm{mol})$ were used without further purification. BPA is directly dissolved in water with a concentration of $1000 \mathrm{mg} / \mathrm{L}$. Standard solutions of bisphenol A were prepared by diluting the $1000 \mathrm{mg} / \mathrm{L}$ stock. Hydrogen peroxide solution (30 $\% \mathrm{w} / \mathrm{w})$ in stable form was provided by Riedel-deHaen Company. All reagents employed were not subjected to any further treatment.

\subsection{Experimental set up}


All experiments were performed in a batch reactor with a cooling jacket. The schematic diagram of the experimental set-up used in the study is shown in Figure 2.

The reactor was cylindrical with $1.5 \mathrm{~L}$ volume and the internal part is made of quartz glass which was available for the transfer of the radiation and the outer part is made of Pyrex glass. Irradiation was achieved by using UV lamp (medium pressure mercury lamp UVOX 300 of $300 \mathrm{~W}, 240-250 \mathrm{~nm}$, from ARDA Company in France) which was immersed in the glass tube and the Ozone gas was produced by Ozonator (ARDA Company, Model COG1, France) which was immersed in the reactor.

The reactor was equipped with a cooling water jacket system. The reactor was filled with the bisphenol A solution. Mixing was accomplished by the use of a magnetic stirrer.

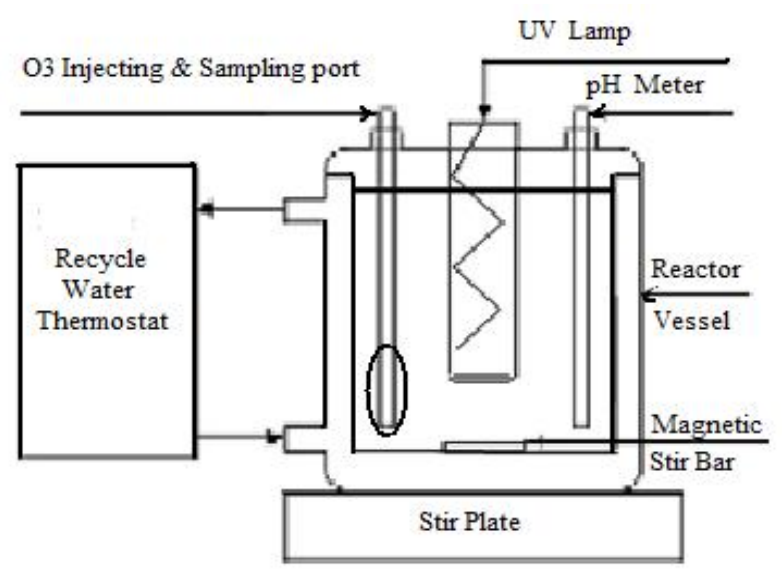

Figure 2. Schematic diagram of photochemical oxidation system experimental set-up.

\subsection{Procedures}

The laboratory unit was filled with $1.5 \mathrm{~L}$ of the bisphenol A solution. The optimum ozone dosage was determined by addition of $\mathrm{O}_{3}$ to BPA solution and the percent degradation of BPA was measured. The optimal hydrogen peroxide concentration was determined by addition of $\mathrm{O}_{3}$ to BPA solution and the percent degradation of BPA was measured. The time at which the ultraviolet lamp was turned on was considered time zero or the beginning of the experiment which was taking place simultaneously with the addition of hydrogen peroxide. The $\mathrm{pH}$ of the sample solution was adjusted with $\mathrm{H}_{2} \mathrm{SO}_{4}$ and/or $\mathrm{NaOH}$ solution. The BPA solution was degraded by $\mathrm{O}_{3}, \mathrm{O}_{3} / \mathrm{H}_{2} \mathrm{O}_{2}$ and $\mathrm{O}_{3} / \mathrm{H}_{2} \mathrm{O}_{2} / \mathrm{UV}$ processes and chemical oxygen demand (COD) of solution was determined

\subsection{Analytical methods}

Samples were taken at appropriate time intervals from the reaction vessel and pipetted into (3 $\mathrm{ml}$ ) glass vials. The vials were filled so as to leave no headspace and sealed with teflon-lined silicon septa and screw caps. The samples were immediately analyzed to avoid further reaction. Concentration changes of bisphenol A were determined by a spectrophotometer (DR2500 , HACH) according to the standard methods [16]. The initial and treated solutions of bisphenol A were determined by the standard methods procedure [16]. The $\mathrm{pH}$ measurements 
were carried out with a Metrohm model $691 \mathrm{pH}$ meter, calibrated with two buffer solutions of 3 and 7. Chemical oxygen demand of solution was determined by COD meter (CR 3200, WTW).

\section{RESULTS AND DISCUSSION}

\subsection{Optimum ozone dosage}

Figure 3 illustrates the percent degradation of BPA as a function of the ozonation time at different doses of $\mathrm{O}_{3}$ input.

By addition of $\mathrm{O}_{3}$, the degradation rate of BPA increased when ozone concentration increased. As can be seen from Figure 3, the percent degradation of BPA at $0.138 \mathrm{mmol} / \mathrm{min}$. ozone dosage was 61.0 (the highest percent) and was 60.0 at $0.166 \mathrm{mmol} / \mathrm{min}$. ozone dosage. Thus the optimum ozone dosage is $0.138 \mathrm{mmol} / \mathrm{min}$.

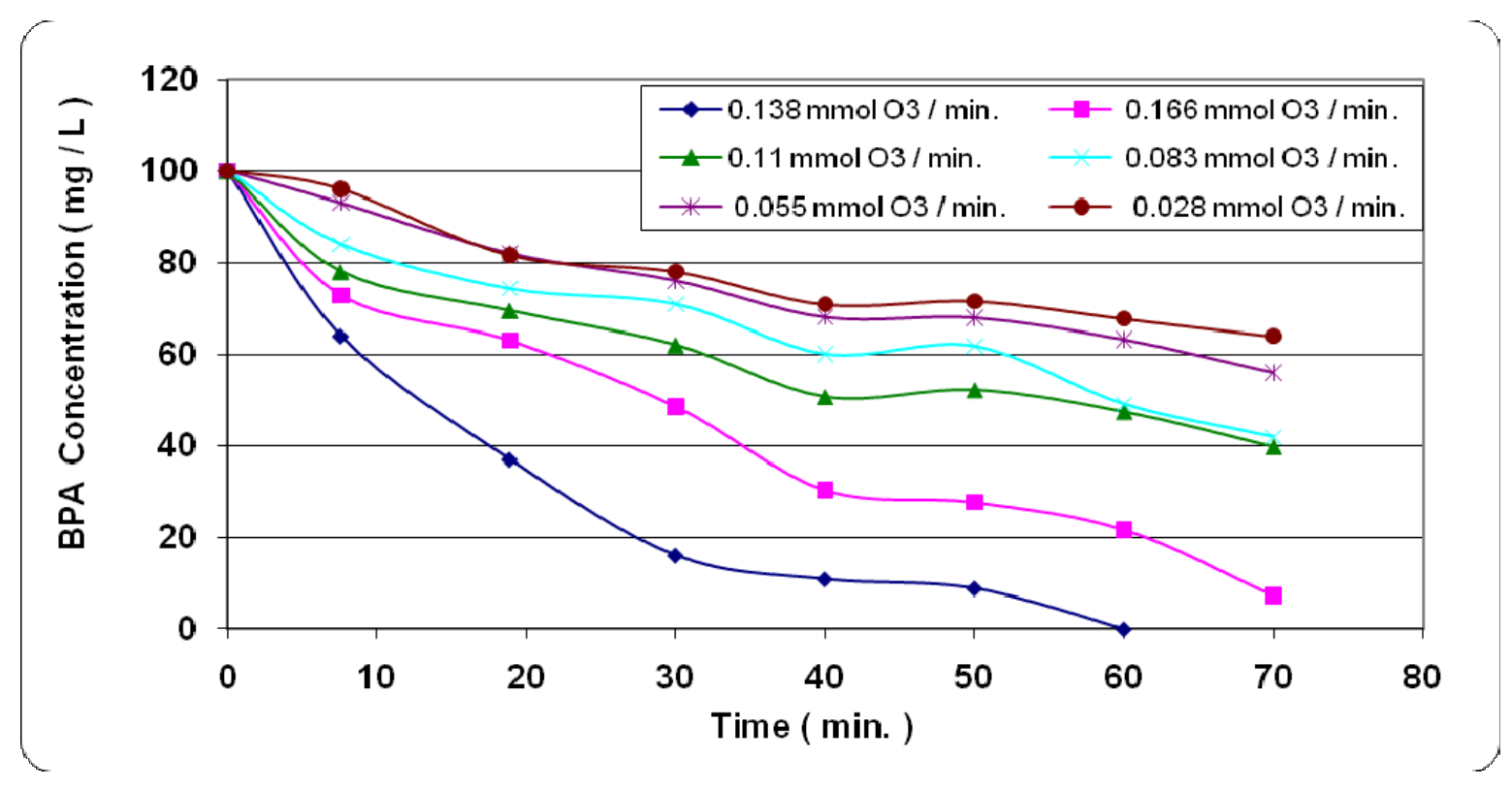

Figure 3. The effect of ozone concentration in degradation of BPA with ozone.

\subsection{Optimum hydrogen peroxide dosage}

When hydrogen peroxide combined with ozone, the rate of BPA degradation increased significantly compared to that of direct ozonation. Figure 4 illustrates the percent degradation of BPA as a function of the irradiation time at different doses of $\mathrm{H}_{2} \mathrm{O}_{2}$ input.

The degradation rate of BPA increased when hydrogen peroxide concentration increased. As can be seen from Figure 4, the percent degradation of BPA at $0.0945 \mathrm{M}$ hydrogen peroxide dosage was 20.30 and was 18.10 at $0.1419 \mathrm{M}$ hydrogen peroxide dosage. In this process, hydroxyl radicals generated from the degradation of hydrogen peroxide were the main responsible species of BPA elimination. Addition of $\mathrm{H}_{2} \mathrm{O}_{2}$ exceeding $0.0945 \mathrm{M}$ for this system did not improve the respective maximum degradation. This may be due to autodecomposition of $\mathrm{H}_{2} \mathrm{O}_{2}$ to oxygen and water and the recombination of $\mathrm{OH} \bullet$ radicals. Since $\mathrm{OH} \bullet$ radicals react with $\mathrm{H}_{2} \mathrm{O}_{2}, \mathrm{H}_{2} \mathrm{O}_{2}$ itself contributes to the $\mathrm{OH}$ scavenging capacity. Therefore, $\mathrm{H}_{2} \mathrm{O}_{2}$ should be added at an optimal concentration to achieve the best degradation. 
Linnaeus ECO-TECH '10

Kalmar, Sweden, November 22-24, 2010

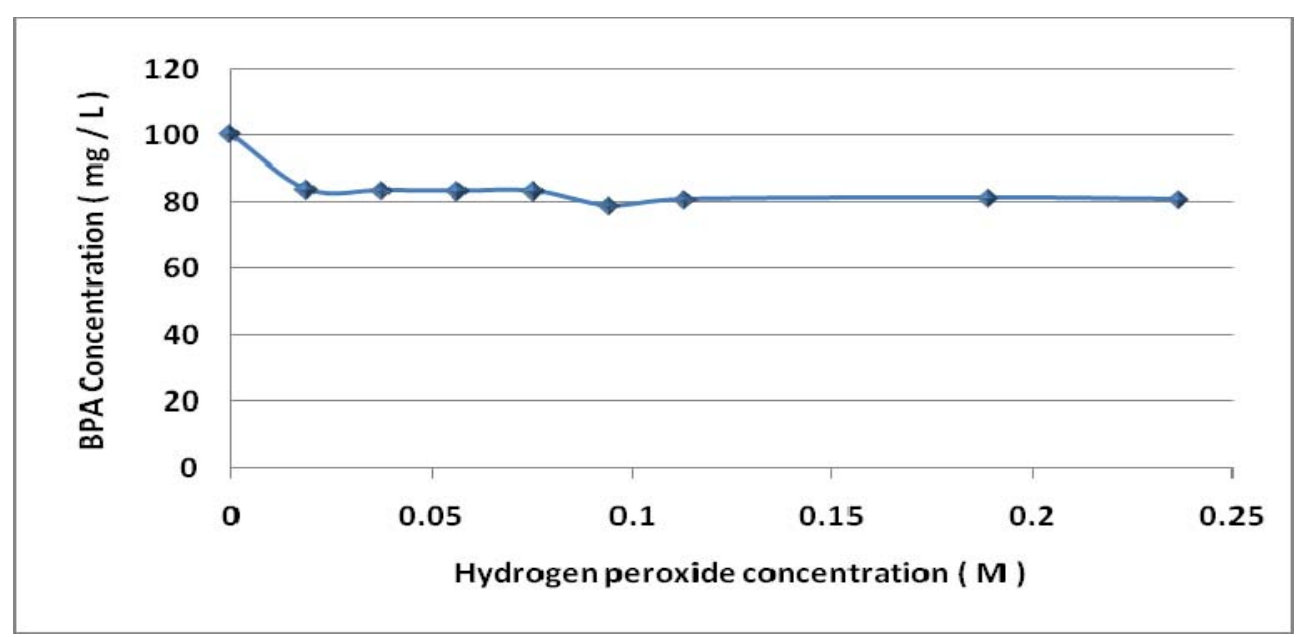

Figure 4. The effect of hydrogen peroxide concentration in degradation of BPA with ozone.

\section{3 $\mathrm{O}_{3} / \mathrm{H}_{2} \mathrm{O}_{2}$ Process}

Figure 5 illustrates the degradation of BPA as a function of the oxidation time at Alkaline $\mathrm{pH}$. By addition of $\mathrm{O}_{3}$, the degradation rate of BPA increased. As can be seen from Figure 5, the percent degradation of BPA was 99.4 and the percent decrease of chemical oxygen demand was 54.5 at 60 minute.

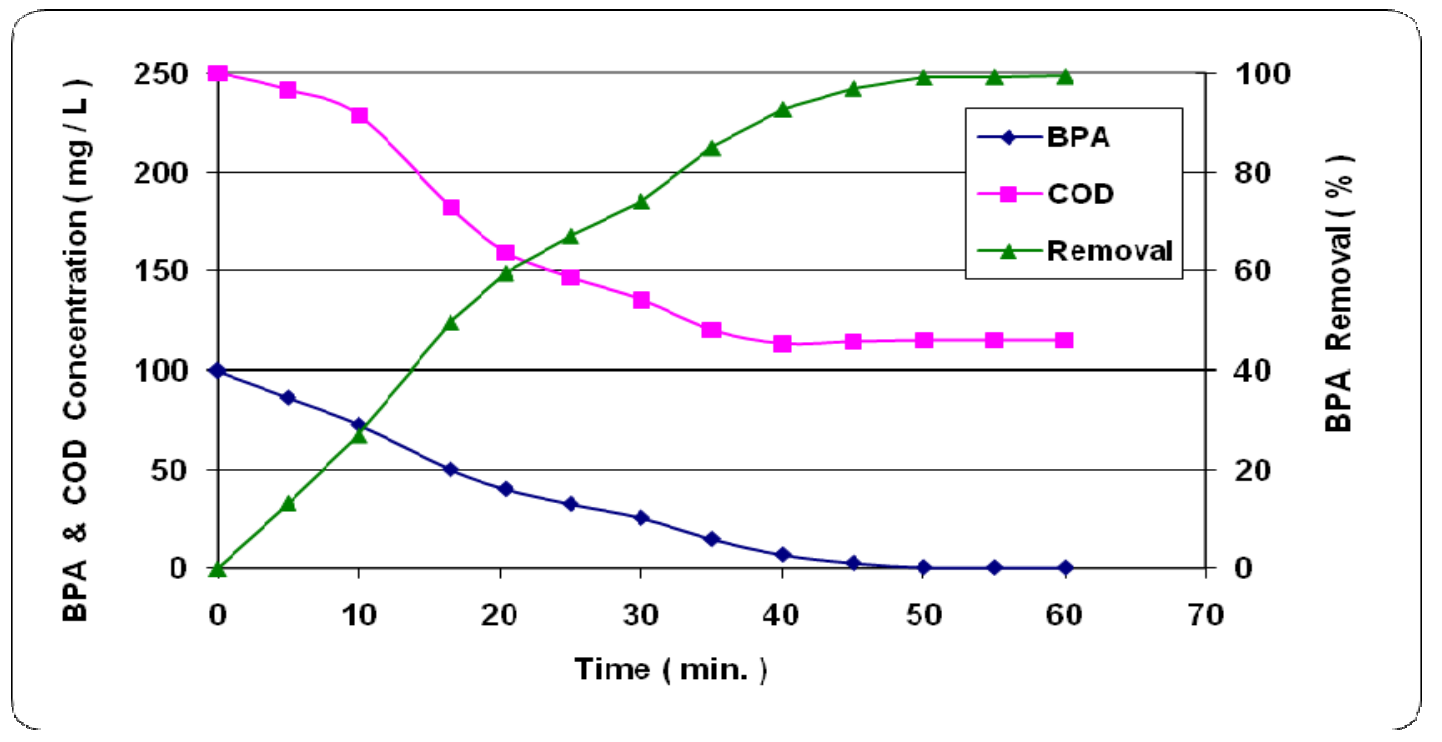

Figure 5. The degradation of BPA with ozone/hydrogen peroxide process.

\section{$3.4 \mathrm{O}_{3} / \mathrm{H}_{2} \mathrm{O}_{2} / \mathrm{UV}$ Process}

Figure 6 illustrates the degradation of BPA as a function of the oxidation time at Alkaline $\mathrm{pH}$. By addition of $\mathrm{O}_{3}$, the degradation rate of BPA increased. As can be seen from Figure 6, the percent degradation of BPA was 99.8 and the percent decrease of chemical oxygen demand was 75.2 at 35 minute. 


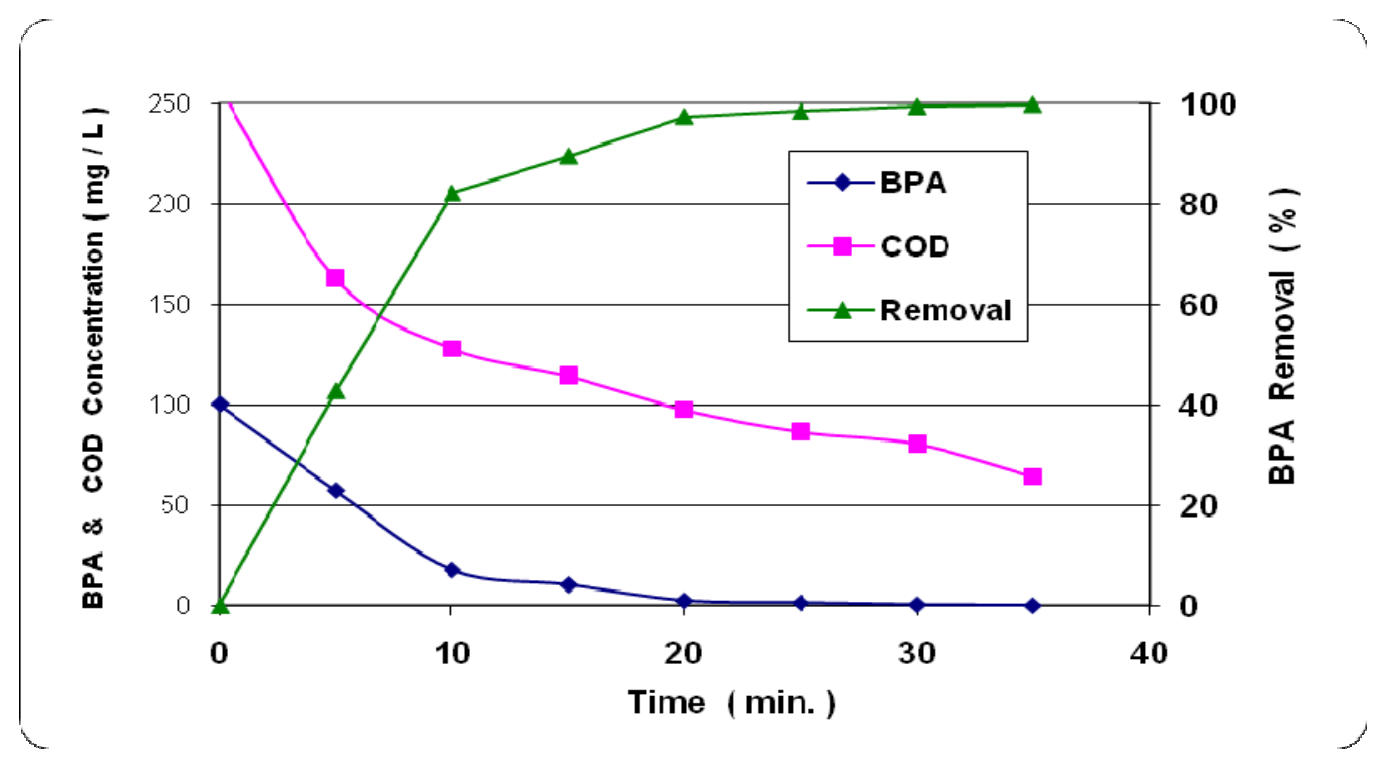

Figure 6. The degradation of BPA with ozone/hydrogen peroxide/UV process.

\subsection{Comparison between advanced oxidation process}

The degradation of BPA was investigated in all systems $\mathrm{O}_{3}, \mathrm{O}_{3} / \mathrm{H}_{2} \mathrm{O}_{2}$ and $\mathrm{O}_{3} / \mathrm{H}_{2} \mathrm{O}_{2} / \mathrm{UV}$. The loss of BPA was observed as a function of oxidation time and data were fitted to a first-order rate model.

$\operatorname{Ln}\left(\mathrm{C}_{1} / \mathrm{C}_{0}\right)=-\mathrm{K}_{0} \mathrm{t}$

where $\mathrm{C}_{0}$ and $\mathrm{C}_{1}$ are the concentration of BPA at oxidation times 0 and $\mathrm{t}, \mathrm{K}_{0}$ is a first-order rate constant $\left(\mathrm{min}^{-1}\right)$ and $\mathrm{t}$ is the oxidation time $(\mathrm{min})$. The rate constants were determined using a first-order rate model (eqn. 12). The results are listed in Table 1.

Table 1. Values of reaction rate constant of the degradation of BPA by different types of advanced oxidation processes

\begin{tabular}{|c|c|}
\hline Type of advanced oxidation process & $\mathrm{K}_{0}\left(\mathrm{~min}^{-1}\right)$ \\
\hline $\mathrm{O}_{3}$ & 0.051 \\
$\mathrm{O}_{3} / \mathrm{H}_{2} \mathrm{O}_{2}$ & 0.093 \\
$\mathrm{O}_{3} / \mathrm{H}_{2} \mathrm{O}_{2} / \mathrm{UV}$ & 0.179 \\
\hline
\end{tabular}

The experimental data in Figure 7 show that $\mathrm{O}_{3} / \mathrm{H}_{2} \mathrm{O}_{2} / \mathrm{UV}$ process had a significant accelerating effect on the rate of oxidation of BPA. The data in Table 1 show that addition of $\mathrm{H}_{2} \mathrm{O}_{2}$ to the $\mathrm{O}_{3}$ system enhanced the rate of BPA oxidation by a maximum factor 1.8 , over the $\mathrm{O}_{3}$ system and addition of UV radiation to the $\mathrm{O}_{3} / \mathrm{H}_{2} \mathrm{O}_{2}$ system enhanced the rate of BPA oxidation by a maximum factor 1.9 , over the $\mathrm{O}_{3} / \mathrm{H}_{2} \mathrm{O}_{2}$ system, depending on both $\mathrm{H}_{2} \mathrm{O}_{2}$ and $\mathrm{O}_{3}$ doses. 


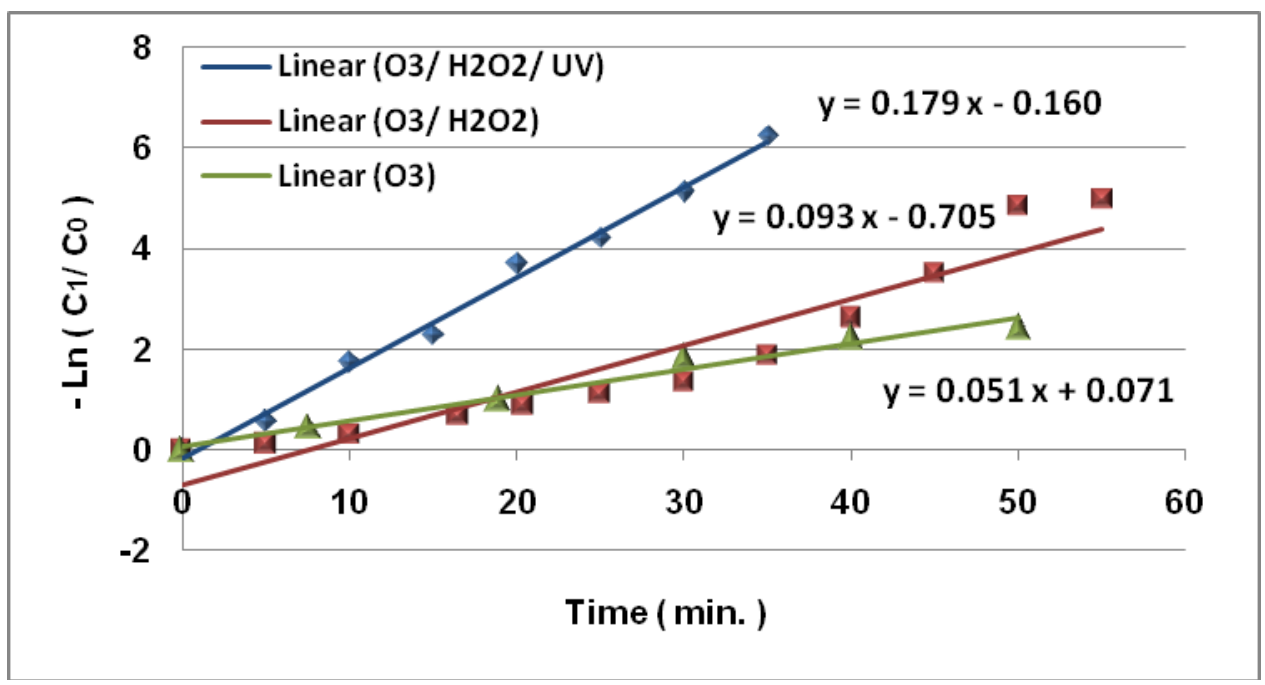

Figure 7. First-order plot for degradation of BPA by $\mathrm{O}_{3}, \mathrm{O}_{3} / \mathrm{H}_{2} \mathrm{O}_{2}$ and $\mathrm{O}_{3} / \mathrm{H}_{2} \mathrm{O}_{2} / \mathrm{UV}$ processes

\section{CONCLUSION}

Bisphenol A (BPA) have been oxidized by $\mathrm{O}_{3}, \mathrm{O}_{3} / \mathrm{H}_{2} \mathrm{O}_{2}$ and $\mathrm{O}_{3} / \mathrm{H}_{2} \mathrm{O}_{2} / \mathrm{UV}$ processes. The initial concentration of BPA was $100 \mathrm{mg} / \mathrm{L}$ solution and kept constant in all treatments. Coupling of UV with $\mathrm{O}_{3} / \mathrm{H}_{2} \mathrm{O}_{2}$ and coupling of $\mathrm{H}_{2} \mathrm{O}_{2}$ with $\mathrm{O}_{3}$ decreased the $\mathrm{O}_{3}$ consumption compared to $\mathrm{O}_{3}$ only. The results indicated that the reaction between $\mathrm{BPA}$ and $\mathrm{O}_{3}$ is slower than the reaction between BPA and $\mathrm{O}_{3} / \mathrm{H}_{2} \mathrm{O}_{2}$.

The optimum concentration of ozone and hydrogen peroxide for degradation of BPA under $\mathrm{O}_{3} / \mathrm{H}_{2} \mathrm{O}_{2}$ system was $0.138 \mathrm{mmol} / \mathrm{min}$ and $0.0945 \mathrm{M}$, respectively. In $\mathrm{O}_{3} / \mathrm{H}_{2} \mathrm{O}_{2}$ system the percent degradation of BPA was 99.4 and the percent decrease of chemical oxygen demand was 54.5 at $60 \mathrm{~min}$.

In complete degradation experiments, 1 mole of BPA reacted with 20.5 moles of $\mathrm{O}_{3}$. BPA complete degradation was achieved after $37 \mathrm{~min}$ under the optimum conditions by $\mathrm{O}_{3} / \mathrm{H}_{2} \mathrm{O}_{2} / \mathrm{UV}$ process.

In $\mathrm{O}_{3} / \mathrm{H}_{2} \mathrm{O}_{2} / \mathrm{UV}$ process the percent degradation of BPA was 99.8 and the percent decrease of chemical oxygen demand was 75.2 at $35 \mathrm{~min}$.

It was found that the primary decomposition reaction follows a first-order kinetic law, and the rate constant, $K_{0}$, was $0.051,0.093$ and 0.179 for $\mathrm{O}_{3}, \mathrm{O}_{3} / \mathrm{H}_{2} \mathrm{O}_{2}$ and $\mathrm{O}_{3} / \mathrm{H}_{2} \mathrm{O}_{2} / \mathrm{UV}$ processes, respectively. The optimum ozone dosage was $0.138 \mathrm{mmol} / \mathrm{min}$. and hydrogen peroxide is $0.0945 \mathrm{M}$.

\section{REFERENCE}

[1] Harries, E., Runnalls, T., Hill, E., Harris, C.A., Maddix, S., Sumpter, J.P., Tyler, C.R., 2000. Environ. Sci. Technol. 34, 3003.

[2] Katsumata, H., Kawabe, S., Kaneco, S., Suzuki, T., Ohta, K., 2004. Degradation of bisphenol A in water by the photo-Fenton reaction, J. Photochem. Photobiol. A: Chem. 162, 297-305. 
[3] Jamshidi, N., Torabian, A., Azimi, A.A. and Ghadimkhani, A.A. 2009. Degradation of phenol in aqueous solution by advanced oxidation process. Asian Journal of Chemistry, 20(1), 673-681.

[4] Torabian, A., Jamshidi, N., Azimi, A.A., Nabi Bidhendi, G.R. and Jafarzadeh, M.T. 2009. Photochemical Oxidation of Phenol in Olefins Plant Effluent by $\mathrm{UV} / \mathrm{H}_{2} \mathrm{O}_{2}$ and Photo-Fenton Processes (Case Study). Asian Journal of Chemistry, 21(7), 5310-5318.

[5] D. Vogna, R. Marotta, A. Napolitano, R. Andreozzi, M. d'Ischia, 2004. Advanced oxidation of the pharmaceutical drug diclofenac with $\mathrm{UV} / \mathrm{H}_{2} \mathrm{O}_{2}$ and ozone, Water Res. $38,414-422$.

[6] H.J. Buysch, 1991. Ullman's Encyclopedia of Industrial Chemistry, 5th ed., VCH, New York.

[7] J.A. Brotons, M.F. Olea-Serrano, M. Villalobos, V. Pedraza, N. Olea, 1996. Xenoestrogens released from laquer coating in food cans, Environ. Health Perspect. 103, 608-612.

[8] B. Crathorne, C.P. Palmer, J.A. Stanley, 1986. High performance liquid chromatographic determination of bisphenol-A diglycidyl ether and bisphenol-F diglycidyl ether in water, J. Chromatogr. 360, 266-270.

[9] D. Roy, M. Palangat, C. Chen, R.D. Thomas, J. Colerangle, A. Atkinson, Z.-J. Yan, 1997. Biochemical and molecular changes at the cellular level in response to exposure to environmental estrogen-like chemicals, J. Toxicol. Environ. Health 50, 1-29.

[10] J. Hoign'e, H. Bader, 1983. Rate constants of reactions of ozone with organic and inorganic compounds in water, Water. Res. 17, 173-183.

[11] J. Staehelin, J. Hoign'e, 1985. Decomposition of ozone in water in the presence of organic solutes acting as promoters and inhibitors of radical chain reactions, Environ. Sci. Technol. 19, 1206-1213.

[12] H. Tomiyasu, H. Fukutomi, G. Gordon, 1985. Kinetics and mechanism of ozone decomposition in basic aqueous solution, Inorg. Chem. 24, 2962-2966.

[13] J. Staehelin, J. Hoign'e, 1982. Decomposition of ozone in water: rate of initiation by hydroxide ions and hydrogen peroxide, Environ. Sci. Technol. 16, 676-681.

[14] W.H. Glaze, J.-W. Kang, D.H. Chapin, 1987. The chemistry of water treatment processes involving ozone, hydrogen peroxide and ultraviolet radiation, Ozone Sci. Eng. 9, 335-352.

[15] X. Wang, X. Huang, C. Zuo, H. Hu, 2004. Kinetics of quinoline degradation by O3/UV in aqueous phase, Chemosphere 55, 733-741.

[16] Standard methods for the examination of water and wastewater 1998. APHA, AWWA, WEF, $20^{\text {th }}$ ed. 